tive chaos as a consequence, is especially at risk of getting out of hand. External inquiries seem to follow each other at intervals of five years or so. The latest development is the publication (last week) of an internal report on the management of CSIRO by a subcommittee of its management board that recommends, in effect, the unscrambling of an earlier reorganization (see page 587). Quite when the new arrangements will be in place is not, at this stage, clear; the board is still searching for a chief executive to run the organization as a whole.

There are two reasons why CSIRO is repeatedly the target of inquiries. One is that Australia is over-governed. There are more politicians in charge of some portfolio of government business, at the level of the states as well as the federal government, than there are urgent and soluble problems for them to tackle. Inquiring into the condition of CSIRO is a natural occupation for the underemployed, but sheer size also makes CSIRO a natural object of curiosity. So, too, does the culture of the organization, which still reflects something of the complacency of the days when CSIRO was virtually synonymous with research in Australia. Now, several universities have reputations in the field that command equal respect.

Nevertheless, there is a case for giving CSIRO a respite from public inquiry. In the past few decades, it has navigated the transition from the comprehensively avuncular research organization it once was, believing that it knew better than others what research Australia needed, to one that recognizes that it must deliver useful intellectual goods to customers who are most often industrial companies (or groupings thereof) or government departments. One of the distinctive features of the organization is that many of its people's first interests lie in basic research. To the extent that they have adapted to the idea that their customers' interests are paramount, they collectively have the opportunity to provide Australia with a practically orientated research organization more alert than would otherwise be the case to the importance of basic research. They should be given a chance to work that out for themselves.

Whether the details of the proposed management reorganization will prove sufficient is another matter. The chief change proposed is that the grouping of 'divisions' (freestanding laboratories) into 'institutes' with similar interests should be abolished. Among other things, that should rid the organization of some of the bureaucracy about which there have been endless complaints. (Some academic researchers say they cannot afford to use CSIRO services because they are too expensive; individual laboratories may be able to be more accommodating.) But then it is proposed that the programmes of individual laboratories should evolve from regular meetings of like-minded laboratory heads and people from headquarters. Much will depend on the spirit in which these discussions take place. How flexible will the bosses be (or be allowed by budgetary constraints to be)? The importance of public accountability notwithstanding, there is a strong case that CSIRO should have the freedom to work out the future pattern pragmatically, case by case.

\section{Russian genome project}

Responsibility for Russia's modest interest in the human genome may be characteristically politicized.

RUSSIA has plenty on its mind just now, the continuing war in Chechenia among other things, but the death of Alexandr Baev on 31 December last year has also forced a decision on the Russian contribution to the international Human Genome Project. Baev, who was 90 when he died, had previously been the biology secretary of the Soviet, then the Russian, Academy of Sciences before being put in charge of Russia's special programme in human genetics. In his earlier incarnation, Baev had been something of a conservative, but he appeared to have taken to his later role with the startled enthusiasm of a chauffeur put in charge of a country's air transport industry.

In truth, Russia's original contribution to the project has not been outstanding. Although formally a member of the unofficial Human Genome Organization, Russia has been too occupied with other things to do much more than keep up with what has happened elsewhere. Working scientists in Russian laboratories have access to the databanks, but more often from copies on magnetic tape than in real time. Yet Russia is not innocent of modern technology in this field. On the contrary, young people seem to have taken to the techniques of molecular biology with flair, sometimes in the knowledge that experience in the field may be a passport to a job elsewhere. None of this, of course, depends on the human genome project.

Baev's death would ordinarily not have been a setback, even though the funds for the Russian Human Genome Project are provided directly by the Ministry of Science. The ministry would have canvassed opinion and appointed a successor and the project would have continued. Baev's natural successor is Professor Andrei Mirzabekov, director of the Engelhardt Institute of Molecular Biology in Moscow, on whom Baev appears to have relied for advice. At Baev's funeral earlier this year, his succession seemed to be assured. But it will not be as simple as it seemed.

A lobby headed by the Novosibirsk academician Dmitry Knorre is now urging on the science minister, Boris Saltykov, that the Russian human genome project should be based at the Institute of Biological Chemistry at Novosibirsk. The argument advanced is that Mirzabakov is frequently overseas. That is so; on the strength of his proposal that the hybridization of random sequences of nucleotides can quickly tell the sequence of a single DNA strand, he now holds a joint appointment with the Argonne National Laboratory in the United States. But what the Novosibirsk cabal says is a disqualification is, in reality, the opposite. It will be some time before Russian science is able to take a commanding lead in this or any other comparable field. Meanwhile, participation in international ventures of this kind is a convenient way of transferring the technology of basic research. Why not give the task to the man best able to bring that about? 